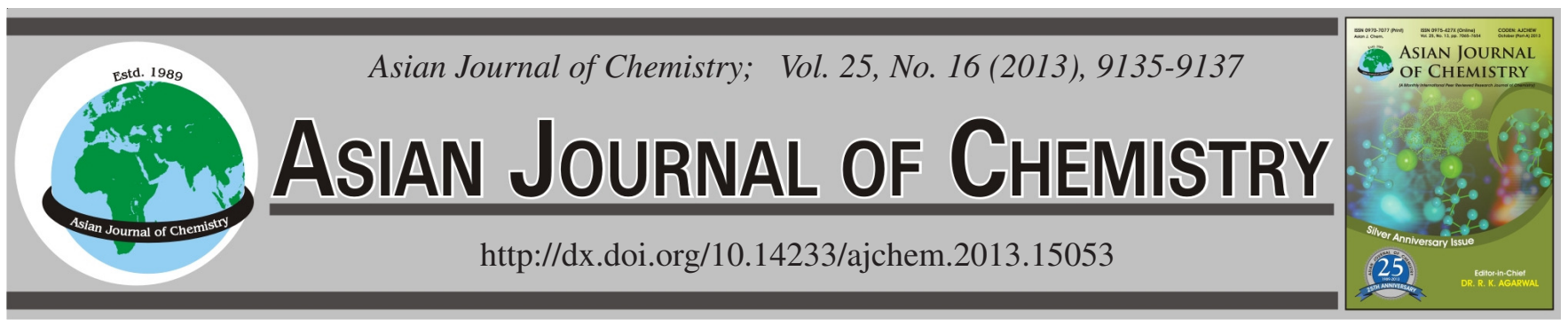

\title{
Comparison of Ozonation and Aeration Methods in Removal of Naphthalene from Aqueous Solution
}

Ehsan Derikvand ${ }^{1}$, Seyyed Mehdi Borghei ${ }^{2}$, Amir Hessam Hassani ${ }^{1, *}$, Seyyed Ahmad Mirbagheri ${ }^{1}$ and Amir Hosein Javid ${ }^{1}$

${ }^{1}$ Department of Environmental Engineering, Science and Research Branch, Islamic Azad University, Tehran, Iran

${ }^{2}$ Department of Chemical and Petroleum Engineering Sharif University of Technology, Tehran, Iran

*Corresponding author: E-mail: dr_ebadi2000@yahoo.com

(Received: 31 December 2012;

Accepted: 18 September 2013)

AJC-14130

\begin{abstract}
High molecular mass of naphthalene make it non-biodegradable and the biological methods for treated the pollutant are much time consuming. In this paper, two methods of ozonation and aeration are used to remove naphthalene. Because of the industrial wastewater has a great range of $\mathrm{pH}$, in this study different concentrations of soluble naphthalene are placed in variable $\mathrm{pH}$ conditions, different contact times and changes in amount of aeration and ozonation. ANOVA results indicated a significant difference between two methods. The average removal of naphthalene by use of ozonation is $55 \%$ and $37 \%$ for aeration. As results, the best conditions that naphthalene are removed is in acidic environment with $\mathrm{pH}<5$ and with increased contact time to 15 minutes and the amount of ozonation and aeration was obtained $3 \mathrm{~L} / \mathrm{min}$. The results also indicated that ozonation is much effective method to remove high concentrations of soluble naphthalene in industrial wastewater.
\end{abstract}

Key Words: Naphthalene soluble, Industrial wastewater, Ozonation, Aeration.

\section{INTRODUCTION}

Today's oil pollutants are hazardous for aquatic ecosystems. Most of these materials are not biodegradable, would remain in the environment for a long time. Existence of some of their compounds such poly-aromatics provide more unfavourable condition ${ }^{1}$. The World Health Organization are classified polycyclic aromatic in-group of primary pollutants. Aromatic compounds cause many problems for human and other organisms. Toxicity of these compounds is proved and with increases the number of rings of these materials their carcinogen properties will be more ${ }^{1,2}$. Poly aromatics are produced from various sources. They formed during the incomplete burning of organic materials or formed during the pyrolysis process and they may have originated from natural products. Among the most important sources of polyaromatic hydrocarbons (PAHs) producing fossil fuels and vehicles and fuel industries can be noted which all are made by man. These materials enter into surface water and the environment through wastewater of treatment effluents ${ }^{1-3}$. These materials have low solubility in water and are highly lipophilic. During the wastewater treatment, process can accumulate in sewage sludge ${ }^{3}$. Polyaromatic hydrocarbons due to their high persistence in the environment are of particular attention and by the Environmental Protection Agency (EPA) and standards of Europe (EU) have been among the primary pollutants list. As far as for use of wastewater treatment plant for agriculture polyaromatic hydrocarbons values always measured ${ }^{3,4}$. The organic material that is virtually insoluble in water composed of two benzene rings, naphtalene that one of them is a two rings poly aromatic. This material has low solubility in water and the maximum is $30 \mathrm{mg} / \mathrm{L}^{3,4}$. Observations show that the use of the material in industries such as petrochemicals, rubber, paint, insecticides and etc., has caused a bit over the limit of this substance into the environment. The biodegradation of naphthalene is not observed therefore, other methods are used for the removal and reduction of it in waste and soil and water resources. The most effective methods for removal of naphthalene from the water resources are chemical oxidation using ozone, Fenton $\left(\mathrm{Fe}^{2+}+\mathrm{H}_{2} \mathrm{O}_{2}\right)$, Photo-Fenton $\left(\mathrm{Fe}^{2+}+\mathrm{H}_{2} \mathrm{O}_{2}+\mathrm{UV}\right)$ and carbon active $^{3,4}$. Studies in this regard emphasize on the use of chemical methods to improve the removal process and reduce polyaromatic hydrocarbons. By removal of organics from municipal wastewater sludge using anaerobic method $50 \%$ of polyaromatic hydrocarbons were removed while removal these materials using ozone and anaerobic processes increased by $81 \%$. Two samples of clay and sand contaminated with phenanthrene (3-ring poly-aromatic) were placed under ozonation. With the amount of $20 \mathrm{mg} / \mathrm{L}$ ozone in the $2 \mathrm{~h}$ elimination of $50 \%$ phenanthrene in the clay soil and $81 \%$ phenanthrene 
in the sandy soil observed and biodegradation condition of phenanthrene was obtained after ozonation ${ }^{6}$.

\section{EXPERIMENTAL}

$30 \mathrm{mg} / \mathrm{L}$ amount of naphthalene in water at temperatures up to $20^{\circ} \mathrm{C}$ can be solved ${ }^{3}$. In this study, using field observations in different industries and naphthalene effluent output of factories, eight different concentrations of naphthalene solution was prepared. A 1.5 L glass vessel was used as a batch. Low concentrations of naphthalene were dissolved in distilled water. For producing high concentrations of naphthalene in solution put into in a closed container with a shaker device with 140 (rpm) rotation for $2 \mathrm{~h}$ and volume for each experiment were considered.

Ozonation condition: Ozone generator of the laboratory type with a maximum ozone production of $1 \mathrm{~g} / \mathrm{h}$. Different amounts of ozone gas flow $(1,2,3) \mathrm{L} / \mathrm{min}$ were tested, ozone produced by a diffusers was out at the bottom of the reactor. The ozone generator device receives produced oxygen from oxygen-generating and converts it to ozone ${ }^{7,8}$.

Aeration condition: Power supply was a laboratory oxygen generator. Exhaust gas from the direct generator entered into the system to check the amount of oxygen removal against the ozone in all cases of ozonation air injected into the system mutually.

Measurement of dissolved naphthalene: Spectrophotometer and HPLC devices were used for measuring the amounts of naphthalene. Absorption values of primary and secondary concentrations of naphthalene were read in the spectrophotometer device at a wavelength of $230 \mathrm{~nm}$. In addition, some of samples were measured by HPLC device to verify the tests ${ }^{8,9}$.

Contact time: Contact times were tested from 1 to 120 min. After initial reviews,contact time of 1 to $15 \mathrm{~min}$ due to the absence of naphthalene in the test environment was reduced to these values. Nine different times were selected for testing.

pH: $\mathrm{pH}$ was one of important investigated factors in the removal of naphthalene. Acidic and alkaline $\mathrm{pH}$ values were examined. In order to preparing alkaline $\mathrm{pH}$ of diluted sodium hydroxid and for acidic $\mathrm{pH}$ of diluted sulfuric acid was used. In this regard five different $\mathrm{pH}$ was studied ${ }^{8,9}$.

\section{RESULTS AND DISCUSSION}

SPSS17 software was used for data analysis. The results indicate that there is a significant difference between the percentage of naphthalene removal using aeration and ozonation methods (Tables 1 and 2). The average percent removal of naphthalene using ozonation method was $55 \%$ and in the aeration method, $37 \%$ were achieved. The high correlation between the ozonation and aeration methods revealed a fact that in the high volume of ozonation removal per cent of naphthalene was extremely high (Table-3).

TABLE-2

COMPARISON OF NAPHTHALENE REMOVAL PERCENTAGE USING OZONATION AND AERATION METHODS

\begin{tabular}{cccc}
\hline Method & Mean & $\begin{array}{c}\text { Standard } \\
\text { deviation }\end{array}$ & $\begin{array}{c}\text { Standard error } \\
\text { of mean }\end{array}$ \\
\hline $\begin{array}{c}\text { Per cent removal } \\
\text { with ozonation }\end{array}$ & 0.555 & 0.428 & 0.0075 \\
$\begin{array}{c}\text { Per cent removal } \\
\text { with aeration }\end{array}$ & 0.378 & 0.413 & 0.00726 \\
\hline
\end{tabular}

TABLE-3

PIERSON CORRELATION INDEX

BETWEEN THE TWO METHODS

\begin{tabular}{ccc}
\hline Correlation coefficient index & $\begin{array}{c}\text { Correlation } \\
\text { coefficient }\end{array}$ & $\begin{array}{c}\text { Significance } \\
\text { level }\end{array}$ \\
\hline $\begin{array}{c}\text { Percent removal with ozonation } \\
\text { per cent removal with aeration }\end{array}$ & 0.827 & 0.000 \\
\hline
\end{tabular}

Different concentrations of naphthalene solutions placed under the same ozonation and aeration condition and observed that by increasing naphthalene concentration the rate of naphthalene removal in the aeration method is associated with greater severity and in the higher concentrations of naphthalene the ozonation method is more efficient (Fig. 1). As for the lower concentrations of $7 \mathrm{mg} / \mathrm{L}$ in less than $10 \mathrm{~min}$ duration using ozonation with $3 \mathrm{~L} / \mathrm{min}$ volume, the removal of $100 \%$ was obtained.

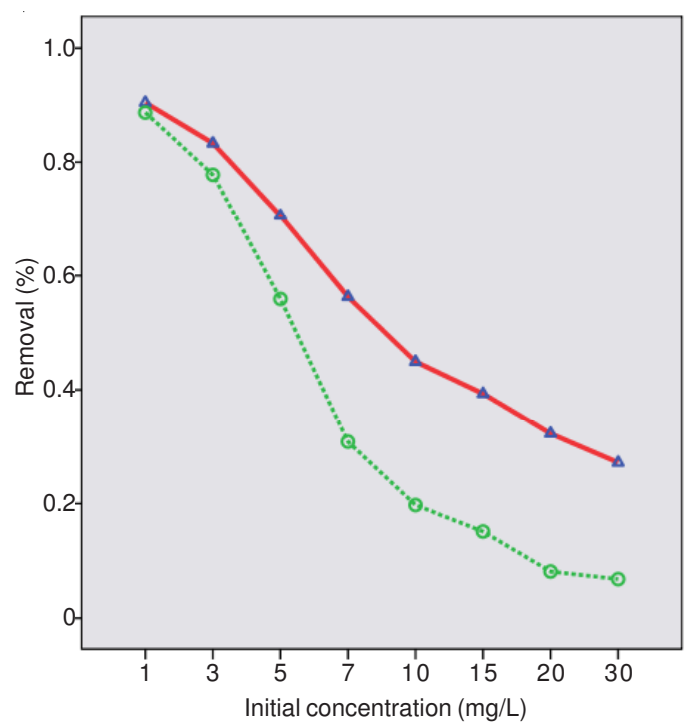

- Ozonation effect ..." Aeration effect $\Delta$ Ozonation effect

Fig. 1. Comparison of naphthalene removal percentage by initial concentration using ozonation and aeration methods

TABLE-1

T-TEST FOR COMPARISON OF REMOVAL PERCENTAGE USING OZONATION AND AERATION METHODS

\begin{tabular}{|c|c|c|c|c|c|c|c|c|}
\hline & \multirow{2}{*}{ Mean } & \multirow{2}{*}{$\begin{array}{c}\text { Standard } \\
\text { error }\end{array}$} & \multirow{2}{*}{$\begin{array}{c}\text { Standard } \\
\text { error of mean }\end{array}$} & \multicolumn{2}{|c|}{$95 \%$ confidence interval } & \multirow{2}{*}{ T-test } & \multirow{2}{*}{$\begin{array}{c}\text { Degrees of } \\
\text { freedom }\end{array}$} & \multirow{2}{*}{$\begin{array}{c}\text { The significance } \\
\text { level }\end{array}$} \\
\hline & & & & Lower bound & Upper bound & & & \\
\hline $\begin{array}{l}\text { Comparison of } \\
\text { ozonation and } \\
\text { aeration method }\end{array}$ & 0.1765 & 0.2476 & 0.0043 & 0.1679 & 0.1850 & 40.57 & 3239 & 0.000 \\
\hline
\end{tabular}


As for effects of environment $\mathrm{pH}$ on removal of naphthalene different acidic and alkaline pHs were studied. Results indicate that with increasing $\mathrm{pH}$, the percentage removal of both methods is reduced but this reduction in ozonation method is far less than aeration method. In other words in all tested $\mathrm{pH}$ ozonation method causes more naphthalene removal (Fig. 2).

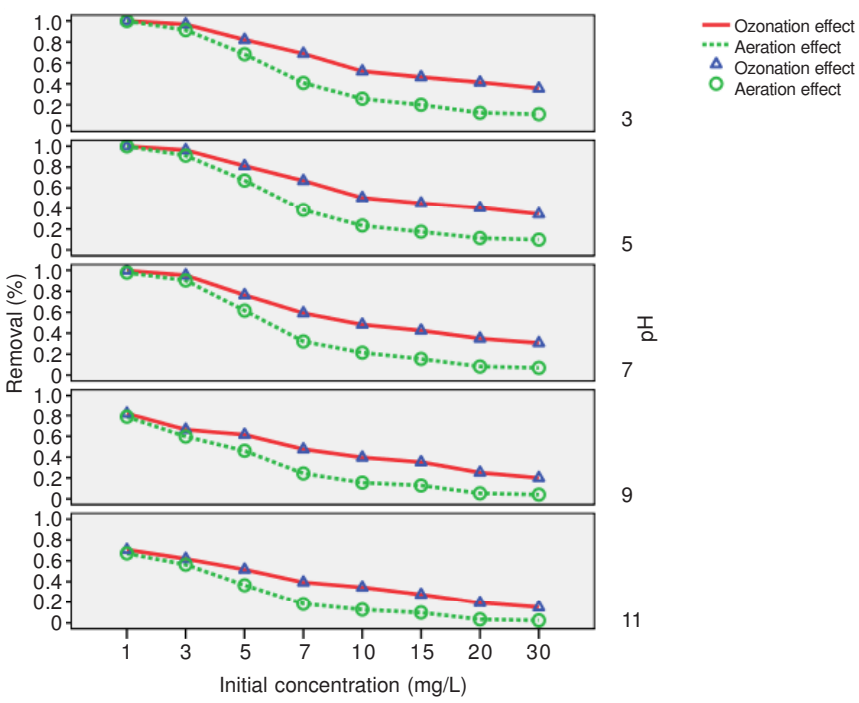

Fig. 2. Comparison of naphthalene removal percentage by $\mathrm{pH}$ and initial concentration using ozonation and aeration methods

After examining the effect of contact time observed that the effect of contact time in this process is consistence with naphthalene removal. In other words, increasing the contact time of air and ozone may increase the percent removal of naphthalene ${ }^{4}$. Results showed that in all cases and for various contact times ozonation method works better and a higher percentage of naphthalene removal will result (Fig. 3).

Only at 1 and 2 minutes,it seems that efficiency of aeration and ozonation methods does not have significant difference.

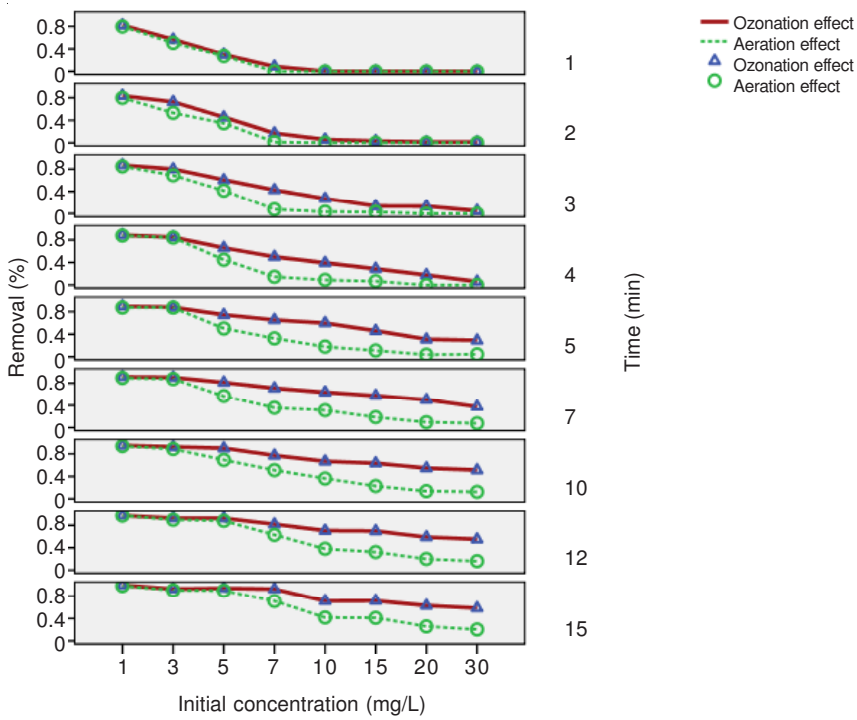

Fig. 3. Comparison of naphthalene removal percentage by $\mathrm{pH}$ and contact time using ozonation and aeration methods
The results also showed that by increasing the $\mathrm{pH}$ and contact time, the percentage of naphthalene removal would reduce. In other words the percentage removal under neutral and acidic $\mathrm{pH}$ in higher contact time, offers a good combination (Fig. 4).

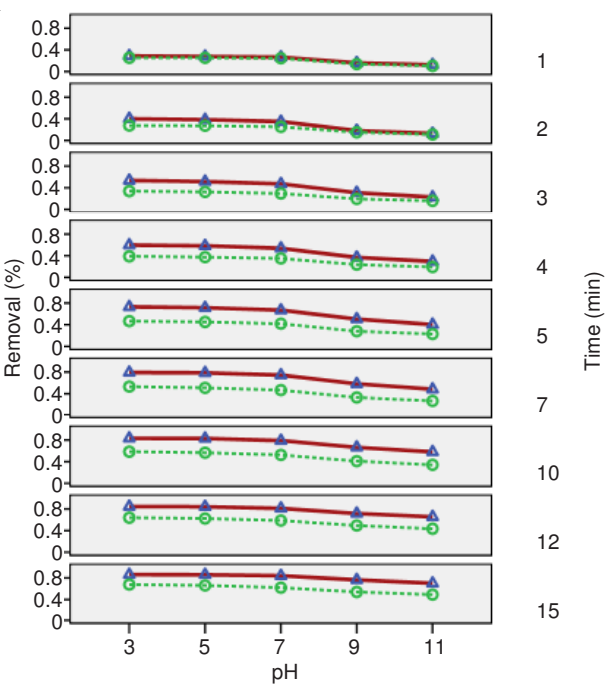

- Ozonation effect -..- Aeration effect $\triangle$ Ozonation effect

Fig. 4. Comparison of naphthalene removal percentage by $\mathrm{pH}$ and contact time using ozonation and aeration methods

\section{Conclusion}

According to demonstrated toxicity and carcinogenesis of polyaromatic hydrocarbons it is necessary to remove these materials from municipal and industrial wastewater. Chemical oxidation using ozonation can be the most appropriate method for the removal of poly cyclic aromatic from environment ${ }^{7,10}$. This study results showed that the efficiency of ozonation method in naphthalene removal is more than aeration method. Optimal conditions for removal of naphthalene solution with increasing contact time and ozonation volume was obtained in an acid environment.

\section{REFERENCES}

1. T. Ali, K. Hossein, S. Laleh, N.B. Gholamreza, A.A. Ali and K.G. Seid, Clean, 38, 77 (2010).

2. B.U. Arodi, C. Helene, P. Dominigue and P.D. Jean, Chemosphere, 68 , 1013 (2007).

3. N. Kyoungphile, R. Wilson and J.K. Jerome, Chemosphere, 45, 11 (2001).

4. S. Zhu, X. Zheng and D. Li, Water Res., 36, 1237 (2002).

5. A. Bernal-Ma, H. Carrere, D. Patureau and J.P. Delgenes, Removal of Polycyclic Aromatic Hydrocarbons by a Serial Combination of Anaerobic Digestion and Ozonation, Sustainable Sludge Management: State of the Art, Challenges and Perspectives. In: IWA Specialized Conference, Moscow, Russia, 29-31 May 2006, pp. 592-598 (2006).

6. A. Goi and M. Trapido, Environ. Technol., 25, 155 (2004).

7. A. Bernal-Martinez, H. Carrere, D. Patureau and J.P. Delgenes, Process Biochem., 40, 3244 (2005).

8. N. Christensen, D.J. Batstone, Z. He, I. Angelidaki and J.E. Schmidt, Water Sci. Technol., 50, 237 (2004).

9. N. Kulik, A. Goi, M. Trapido and T. Tuhkanen, J. Environ. Manage., 78, 382 (2006).

10. R. Goel, T. Tokutomi, H. Yasui and T. Noike, Water Sci. Technol., 48, 85 (2003). 